\title{
Economic Downturns and Land-Use Change: A Spatial Analysis of Urban Transformations in Rome (Italy) Using a Geographically Weighted Principal Component Analysis
}

\author{
Antonio Tomao ${ }^{1,2, *(\mathbb{D}}$, Walter Mattioli ${ }^{3} \mathbb{D}$, David Fanfani ${ }^{4}$, Carlotta Ferrara ${ }^{3}$, Giovanni Quaranta ${ }^{5} \mathbb{D}_{\text {, }}$ \\ Rosanna Salvia ${ }^{5}$ iD and Luca Salvati ${ }^{2}$
}

check for

updates

Citation: Tomao, A.; Mattioli, W.; Fanfani, D.; Ferrara, C.; Quaranta, G.; Salvia, R.; Salvati, L. Economic Downturns and Land-Use Change: A Spatial Analysis of Urban Transformations in Rome (Italy) Using a Geographically Weighted Principal Component Analysis. Sustainability 2021, 13, 11293. https:// doi.org/10.3390/su132011293

Academic Editor: Vida Maliene

Received: 2 September 2021

Accepted: 5 October 2021

Published: 13 October 2021

Publisher's Note: MDPI stays neutral with regard to jurisdictional claims in published maps and institutional affiliations.

Copyright: (C) 2021 by the authors Licensee MDPI, Basel, Switzerland. This article is an open access article distributed under the terms and conditions of the Creative Commons Attribution (CC BY) license (https:// creativecommons.org/licenses/by/ $4.0 /)$.
1 Council for Agricultural Research and Economics (CREA), Research Centre for Forestry and Wood, Viale Santa Margherita 80, I-52100 Arezzo, Italy

2 Department of Economics and Law, University of Macerata, Via Armaroli 43, I-62100 Macerata, Italy; luca.salvati@unimc.it

3 Council for Agricultural Research and Economics (CREA), Research Centre for Forestry and Wood, Via Valle Della Quistione, 27, I-00166 Rome, Italy; walter.mattioli@crea.gov.it (W.M.); carlotta.ferrara@crea.gov.it (C.F.)

4 Architecture Department, University of Florence, Via Della Mattonaia 8, I-50121 Florence, Italy; david.fanfani@unifi.it

5 Mathematics, Computer Science and Economics Department, University of Basilicata, Viale Dell'Ateneo Lucano, I-85100 Potenza, Italy; giovanni.quaranta@unibas.it (G.Q.); rosanna.salvia@unibas.it (R.S.)

* Correspondence: antonio.tomao@crea.gov.it

\begin{abstract}
Globally, processes that drive urbanization have mostly evolved within economic downturns. Economic crises have been more severe and frequent, particularly in the Mediterranean region. However, studies on the recession effects on urbanization are limited. The present study explores possible differences in spatial direction and intensity of land-use change trajectories at two time intervals (2006-2012, 2012-2018) using high-resolution Copernicus Land Urban Atlas images in the Rome metropolitan area. To this aim, a landscape ecology classical approach based on land-use metric analysis combined with a multivariate spatial analysis has been carried out. Results have identified different land-use change patterns during expansion and recession. "Greening", defined as the conversion of urban marginal areas into croplands and forests, increased during the recession. At the same time, the rate of urban expansion into rural areas decreased, thus indicating a beneficial effect of economic downturns in reducing urban sprawl.
\end{abstract}

Keywords: economic crisis; land-use change; land-use trajectories; urban sprawl; geographically weighted principal component analysis; Italy

\section{Introduction}

Over the past decades, rapid demographic, economic, and urban expansions have pushed a massive movement of resources and people, especially in most developed countries [1-4]. This phenomenon has been widely investigated, demonstrating the strong relationship between urbanization processes and the economic conditions during expansion and recession periods [5-8]. In particular, metropolitan sustainability has been demonstrated to be associated with both wealth increase and public finances condition $[9,10]$. Economic conditions have been proven to also influence the effects of urban planning. Indeed, planning tools, such as urban growth boundaries, were more effective to promote urban development within the delimited area during economic expansion than during recession. The same result has been found for the efficiency of agricultural zoning in limiting urban expansion [11].

The scientific debate about this issue has recently grown in Europe [12,13], where there have been discussions on how, despite their intrinsic diversity, cities' growth trajectories 
are increasingly associated with many socioeconomic and environmental factors, whose impact varies with economic downturns [5,14-16]. In particular, urbanization dynamics changed drastically after the 2007 crisis in Mediterranean cities, shifting from an increase in urban sprawl to settlement densification close to the inner cities [17-19]. An example of these land-use change trajectories is reported by a recent study in the metropolitan area of Athens [19], where the authors suggest how the crisis may be considered as a chance to revisit urban expansion models, promoting sustainable and resilient urban areas [18,19].

Research about this topic has mostly used classic landscape analysis, analyzing landuse changes, and linking morphology with urban functions [20-25]. However, a step forward to better understand the multi-dimensionality of the urbanization processes and their association with societal, economic, and territorial domains can be done by also considering the spatial interactions among single patches of change. In this regard, a promising technique that can be used to complement traditional approaches is the geographically weighted (GW) principal component analysis (PCA). The GW-PCA, consisting of a series of localized PCAs, has the advantage of analyzing spatial data locally, accounting for their spatial heterogeneity, thus providing a better description at each target location and, at the same time, allowing for a local change identification in the multivariate data [26-28].

In this context, the present study aims to assess if recent land-use change trajectories differed between expansion and recession periods (2006-2012, 2012-2018) in a typical Mediterranean metropolitan area (Rome, Italy). Previous research has used these time spans as exemplary periods to study land-use dynamics during economic expansion and recession [19]. Therefore, due to the delayed and long-lasting impacts of the 2007 recession on land-use change, the 2012-2018 period was considered indicative of the association between land-use dynamics and the economic crisis [19]. This work employed high-resolution Copernicus Land Urban Atlas images to detect land-use change patterns during expansion and recession, applying a landscape ecology approach combined with a multivariate spatial analysis (GW-PCA). Results have identified diversified land-use change dynamics during expansion and recession, indicating that economic downturns had a beneficial effect on urban sprawl containment, while increasing the conversion of urban marginal areas into croplands and forests.

\section{Materials and Methods}

\subsection{Study Area}

The study area includes the statutory Rome metropolitan area $\left(6169 \mathrm{~km}^{2}\right)$ which corresponds to the large urban zones (LUZ) of the Urban Audit program comprising the city core and its commuting zone. One hundred and twenty-two Nuts-3 municipalities are included in the Rome metropolitan area, among which, the Rome municipality (the largest in Europe) extends $1285 \mathrm{~km}^{2}$. The study area is made up of approximately $30 \%$ lowlands (elevations below $100 \mathrm{~m}$ asl), 50\% uplands (elevations between 100 and $500 \mathrm{~m}$ asl), and $20 \%$ mountains (elevations above $500 \mathrm{~m}$ asl). The climate is typical of the Mediterranean area, with mild winter temperatures, and rainfall concentrated mainly in autumn and spring $[5,29]$.

Rome has been considered an example of the expansion paths typical of contemporary Mediterranean cities. Indeed, Rome represents a metropolitan area that has evolved from a nearly dense morphology to a fragmented and chaotic urban shape since the late 1980s [5,29].

\subsection{Land-Use Data}

Land-use data were derived from high-resolution maps $(1: 10,000)$ of the Copernicus Land Urban Atlas (UA) project (Figure 1). According to the theoretical framework proposed by Tomao et al. [19], seven trajectories were identified, referring to (i) "brownfield development", i.e., residential densification, sprawl, and industrial development on urban land-uses, (ii) "greenfield development", i.e., industrial development or compact and dispersed expansion of residential settlements on natural land-uses, and (iii) "greening", 
i.e., transitions from an "urban" land-use (such as dump sites, construction areas, land without current use) to cropland or forests. In particular, the main land-use trajectories in the study area have been classified as follows: $1=$ residential densification on brownfields; $2=$ residential extensification on brownfields; 3 = industrial development on brownfields; 4 = compact expansion of residential settlements on greenfields; 5 = sprawled expansion of residential settlements on greenfields; $6=$ industrial development on greenfields; 7 = greening (for further details see Tomao et al. [19]).
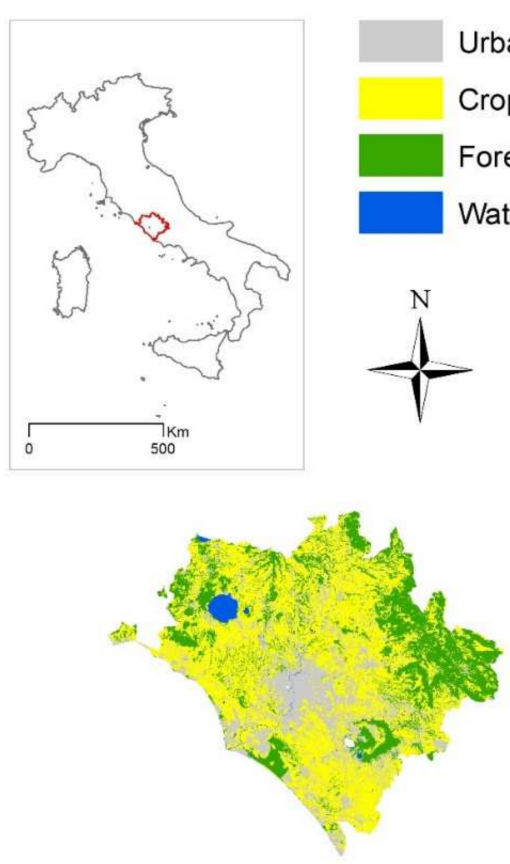
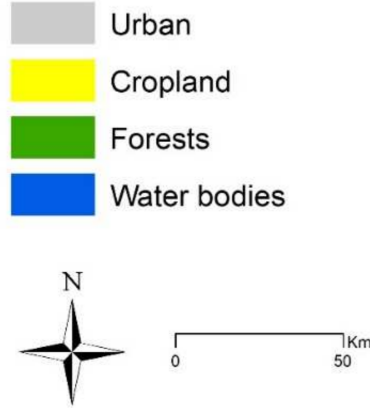

2006
2012

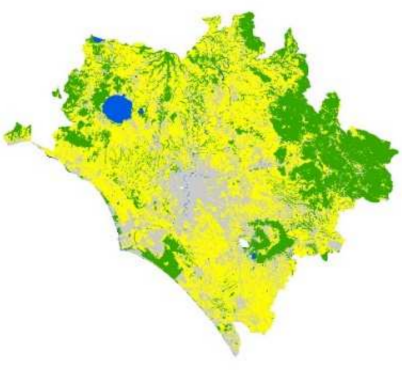

2018

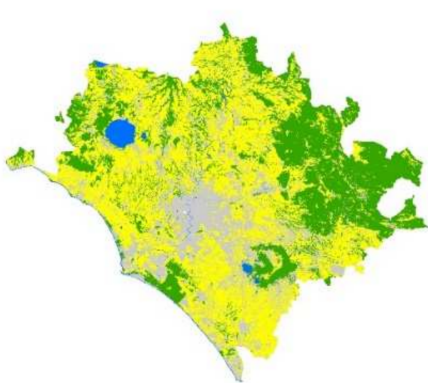

Figure 1. Main land-use categories at the years 2006, 2012, and 2018 for the study area. According to Tomao et al. [19], the displayed classes have been reclassified into urban, cropland, forests, and water bodies classes. Source: own elaboration from Copernicus Land Urban Atlas maps.

Five landscape/class metrics were calculated for each patch experiencing land-use change and each time interval: number of patches; mean patch size; class area in the landscape under transformation; perimeter-to-area $(\mathrm{P} / \mathrm{A})$ ratio; and mean distance from the center of Rome, i.e., "Piazza Barberini" $\left(41^{\circ} 54^{\prime} 13^{\prime \prime}\right.$ N, $12^{\circ} 29^{\prime} 19^{\prime \prime}$ E) [30,31].

\subsection{Statistical Analysis}

A spatially explicit GW-PCA was performed on a matrix of ten descriptors for each patch of change: three landscape metrics (patch size, P/A ratio, distance from downtown) and seven dummies ( $0-1$ values) by individual patch, separately for each time interval [32,33]. The patch centroid spatial coordinates were used as the unit geo-referenced location [19]. GW-PCA allowed us to assess the spatial variation of the individual patches, as well as the influence of the variables on each spatially varying component [26-28]. Significant components were retained using 1 as the minimum eigenvalue threshold, according to the scree-plot criterion. Component loadings were used to identify the multivariate spatial relationship among the land-use trajectories and landscape metrics, thus evaluating patch spatial patterns and evidencing the highest influence of each variable on land-use change through time. All statistical analyses were performed using the "GWmodel" package of the R software $[27,28]$. 


\section{Results}

\subsection{Urban Expansion}

In the first time interval, the number of patches where a land-use change occurred was 7602, for a total area of 8532 ha (approximately $1.4 \%$ of the total LUZ) (Figure 2). In the second period, the number of land-use change patches decreased up to 2353, corresponding to a total area of 3480 ha (nearly $0.56 \%$ of the LUZ).

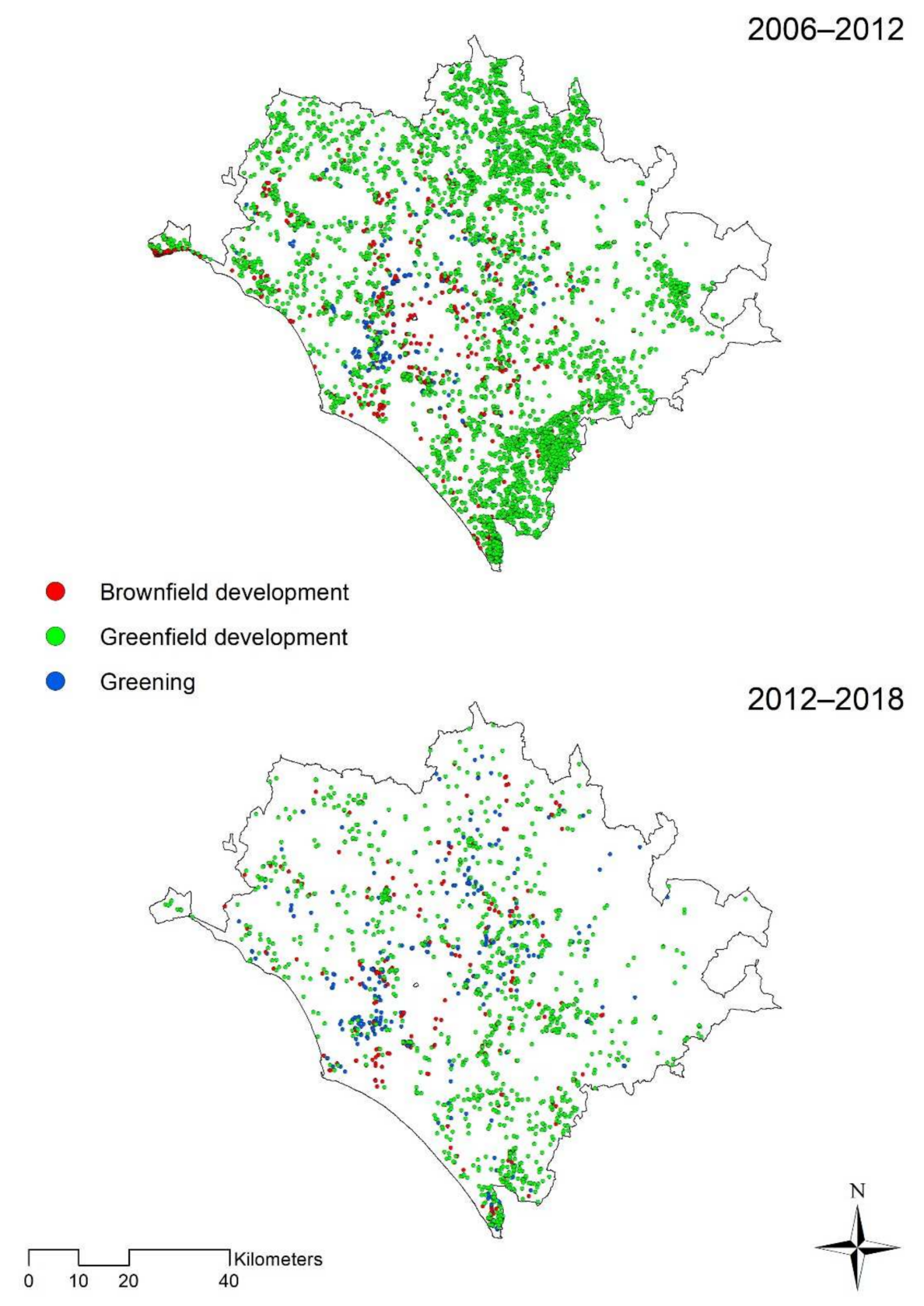

Figure 2. Spatial distribution of the patches experiencing land-use change in the two study periods according to the reclassification into the three land-use trajectories.

Focusing on the urban expansion, intended as the conversion into artificial uses of natural lands, such as croplands or forests (Figure 3), it has been found that these landuse changes account for around $65 \%$ and $40 \%$ of the total changes for the 2006-2012 and 2012-2018 periods, respectively. 


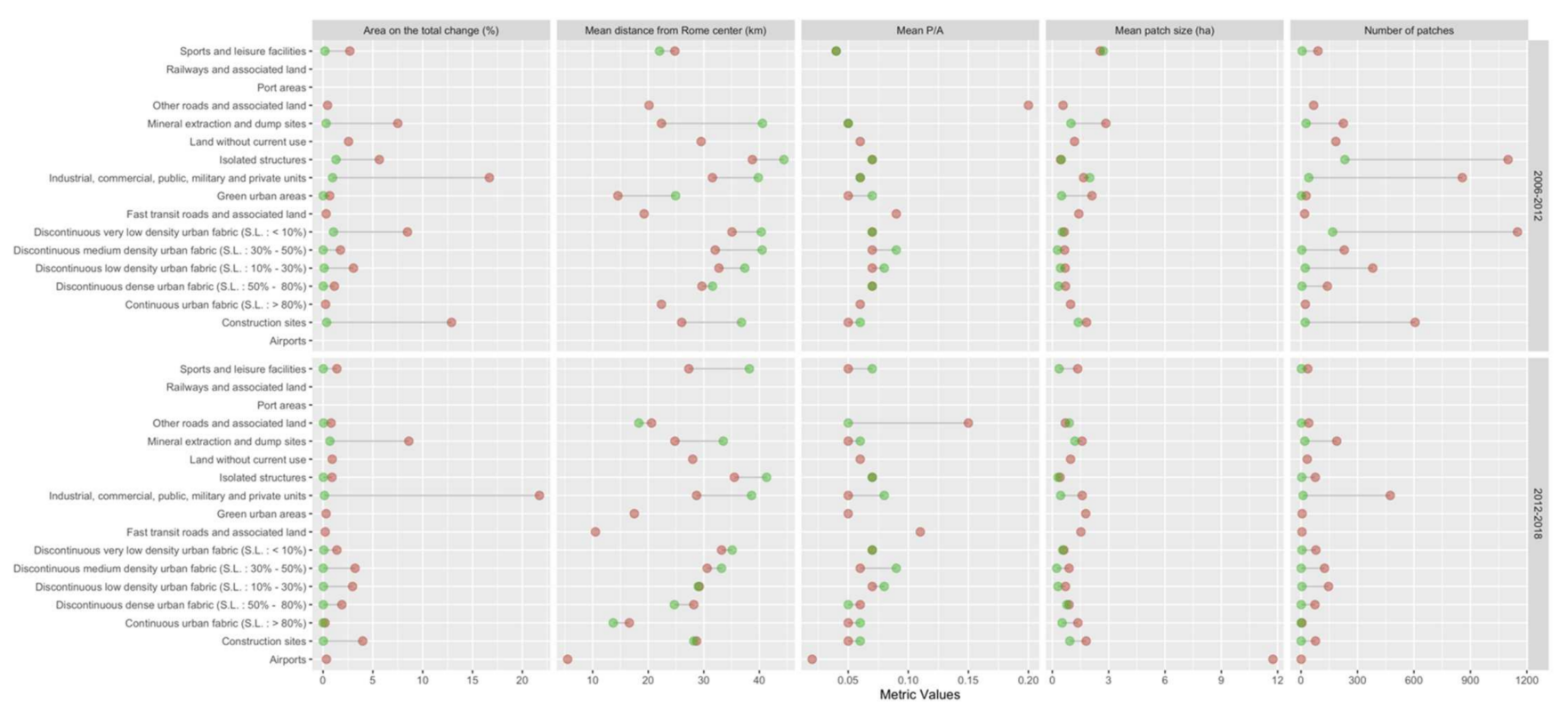

Figure 3. Urban land-use changes of cropland (red dots) and forest (green dots) patches in the Rome metropolitan area for each metric, by time interval.

Between 2006 and 2012, the dispersed urban fabrics expanded considerably into croplands, but not significantly into forests. Hence, a total of 3054 individual patches of greenfields were converted into landscapes hosting isolated structures or residential settlements with a density of sealed land lower than $30 \%$. In this regard, the highest frequency of change was found for conversion into the "discontinuous very low-density urban fabric (with sealed land $<10 \%$ )" class, primarily representing urban sprawl. The patches under change towards discontinuous urban fabric were characterized by a relatively modest average size (0.44-0.68 ha), but a moderately high $\mathrm{P} / \mathrm{A}$ ratio, indicating patches with convoluted shapes. These changes represent more than $15 \%$ of the total changes throughout the entire period. The mean distance from the center of Rome of these patches ranged between $32 \mathrm{~km}$ and $44 \mathrm{~km}$, showing that they are located in fringe areas further from Rome.

Industrial and commercial development was also a relevant conversion of greenfields, involving around $18 \%$ of the total area with changes. These changes involved mediumlarge patches (1.66-1.99 ha) at moderate distances from Rome (31-39 km). Conversion of rural areas (agricultural or forest) into construction sites or dump sites accounted for more than $20 \%$ of the total change. Similarly to the industrial development results, patches undergoing these conversions were characterized by large sizes (0.99-2.8 ha), but were located closer to the center of Rome, at least in the case of the conversion of agricultural areas $(22-26 \mathrm{~km})$.

In the 2012-2018 period, the rate of expansion into greenfields of low-density $(<10 \%$ or between 10 and $30 \%$ of sealed land) residential settlements or isolated structures was lower than in the first period. Although very variable, the average distance from Rome decreased compared to the previous period.

Industrial development was the main land-use change that occurred in rural land, involving more than $20 \%$ of the total change ( 474 individual patches). These conversions comprised medium-large patches, especially in agricultural areas (1.59 ha), with a rather low $\mathrm{P} / \mathrm{A}$ ratio. Change of rural areas (agricultural or forest) into dump sites or construction sites accounted for around $14 \%$ of the overall change. Moreover, similarly to the industrial development results, these patches were characterized by large sizes (0.9-1.8 ha), and situated at varying distances from Rome (17-28 km). 


\subsection{Comparing Trajectories of Land-Use Change}

A comparison of land-use change trajectories over the two considered periods is reported in Table 1. Seven transformations impacting urban landscapes and rural territories have been considered, following the classes proposed in Table 1: urban changes (differentiating expansion on greenfields from brownfield development), and transition from urban to non-urban use (cropland or forest). Brownfield development rates varied across the two time spans, with 2006-2012 being more intense than the subsequent period. Figure 4 shows the trajectory variation percentage by landscape/class metrics between the two time periods. In the first period, residential densification and extensification of built-up areas on brownfields occurred in 568 and 328 patches, respectively (more than $11 \%$ of the study area undergoing change), whereas only 76 and 149 patches were involved in 2012-2018. Despite the number decrease in the second period, the average size of the patches increased (from $0.96-1.11$ ha in 2006-2012 to 1.19-1.44 ha in 2012-2018) and the distance from downtown Rome decreased, especially for new dense settlements (from 31 to $21 \mathrm{~km}$ ). The rate of industrial development on built-up areas did not change substantially between periods, but the distance from Rome greatly decreased (from 31 to $22 \mathrm{~km}$ ).

Table 1. Summary of the land-use trajectories in the Rome metropolitan area, for each time interval.

\begin{tabular}{|c|c|c|c|c|c|}
\hline Land-Use Trajectory & $\begin{array}{c}\text { Number of } \\
\text { Patches }\end{array}$ & $\begin{array}{c}\text { Mean Patch } \\
\text { Size (ha) }\end{array}$ & $\begin{array}{l}\text { Area on the Total } \\
\text { Land-Use Change } \\
(\%)\end{array}$ & $\begin{array}{c}\text { Mean P/A } \\
\text { Ratio } \\
\left(\mathrm{m}^{-1}\right)\end{array}$ & $\begin{array}{c}\text { Distance from } \\
\text { Rome Center } \\
(\mathbf{k m})\end{array}$ \\
\hline \multicolumn{6}{|c|}{ 2006-2012 } \\
\hline \multicolumn{6}{|l|}{ Brownfield development } \\
\hline Residential densification & 568 & 1.11 & 7.40 & 0.060 & 31.2 \\
\hline Residential extensification & 328 & 0.96 & 3.70 & 0.061 & 27.6 \\
\hline Industrialization & 19 & 0.56 & 0.13 & 0.072 & 31.5 \\
\hline \multicolumn{6}{|l|}{ Greenfield development } \\
\hline Compact residential expansion & 168 & 0.72 & 1.42 & 0.072 & 28.7 \\
\hline Residential sprawl & 3288 & 0.56 & 21.39 & 0.069 & 36.8 \\
\hline Industrialization & 984 & 1.60 & 18.41 & 0.067 & 30.9 \\
\hline Greening & 229 & 2.28 & 6.13 & 0.053 & 17.5 \\
\hline Other trajectories & 2018 & 1.75 & 41.43 & 0.058 & 23.4 \\
\hline Total & 7602 & 1.12 & 100.0 & 0.065 & 30.9 \\
\hline \multicolumn{6}{|c|}{$2012-2018$} \\
\hline \multicolumn{6}{|l|}{ Brownfield development } \\
\hline Residential densification & 76 & 1.44 & 3.14 & 0.051 & 20.93 \\
\hline Residential extensification & 149 & 1.19 & 5.08 & 0.056 & 26.89 \\
\hline Industrialization & 8 & 0.40 & 0.09 & 0.125 & 22.68 \\
\hline \multicolumn{6}{|l|}{ Greenfield development } \\
\hline Compact residential expansion & 81 & 0.91 & 2.12 & 0.064 & 27.30 \\
\hline Residential sprawl & 441 & 0.68 & 8.62 & 0.069 & 31.61 \\
\hline Industrialization & 534 & 1.52 & 23.27 & 0.062 & 28.07 \\
\hline Greening & 262 & 2.56 & 19.24 & 0.050 & 22.97 \\
\hline Other trajectories & 802 & 1.67 & 38.44 & 0.058 & 24.53 \\
\hline Total & 2353 & 1.48 & 100.00 & 0.060 & 26.61 \\
\hline
\end{tabular}

Regarding urban expansion into greenfields, the establishment of new compact settlements occurred in 168 patches in the first period (1.4\% of the landscape under change). During 2012-2018, this land-use trajectory was less frequent (81 patches, $2.1 \%$ of the landscape), even with an increase in the average size (from 0.7 to 0.9 ha), as well as a minor reduction of the distance from downtown Rome (from 28 to $27 \mathrm{~km}$ ). Concerning dispersed settlements, residential sprawl into rural landscapes was the most important land-use trajectory in 2006-2012 (3288 patches, 21\% of the landscape). Despite a relevant decrease in the number of patches (441) during 2012-2018 period, this trajectory still accounts for $8.6 \%$ of the landscape under change, with a relevant reduction of the distance from Rome (from $36 \mathrm{~km}$ to $31 \mathrm{~km}$ ). Industrial development on greenfields comprised around 1000 patches 
in the first period and 400 in the second. The average patch size (1.6 and $1.5 \mathrm{ha}$ ) remained nearly constant, and the average distance from Rome experienced a slight increment (28 and $31 \mathrm{~km}$ ).

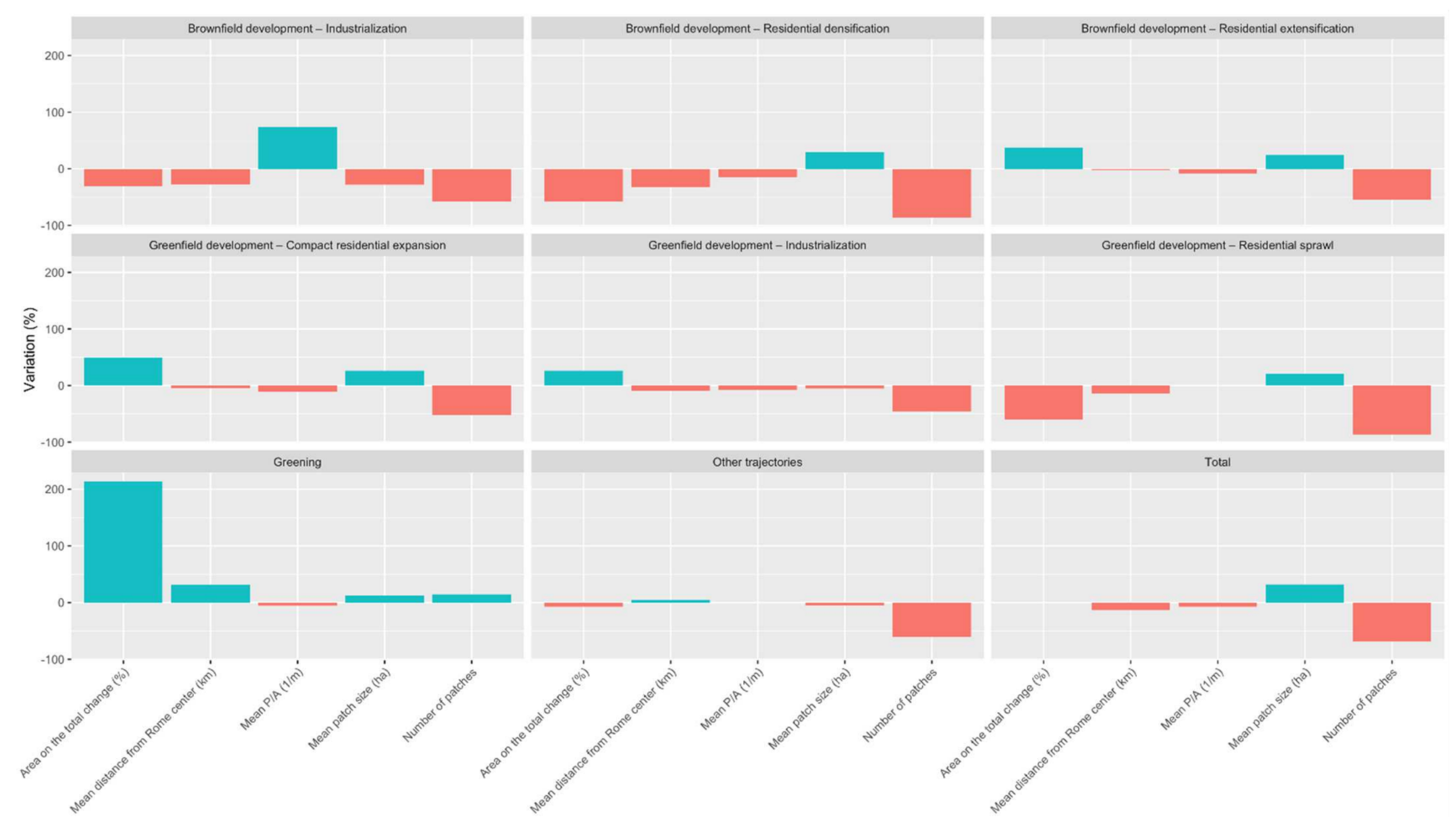

Figure 4. Change over time (trajectory variation percentage increase (blue), or decrease (red)) by landscape metric between 2006-2012 and 2012-2018.

Greening represented a relevant process in both periods. From 2006 to 2012, the conversion of marginal patches classified as "urban" into agricultural land or forests occurred on 229 patches, characterized by a relatively large area (2.3 ha) and a low P/A ratio (0.05). Greening patches were also, on average, those with a lower distance from Rome. In the second period, both the total number of patches (262) and mean size (2.5 ha) slightly increased. The relative importance over the selected land-use trajectories tripled, reaching $19 \%$ of the landscape under change. Distance from downtown Rome also greatly increased, reaching $23 \mathrm{~km}$ on average.

\subsection{Spatial Analysis of Land-Use Trajectories}

Table 2 reports the results of the GW-PCA analysis. Four significant axes were extracted in both time periods, accounting for $54.4 \%$ and $55.5 \%$ of the total variance, respectively. The structure of component loadings shows differences between periods. With economic expansion (2006-2012), Component 1 indicates an urban-rural gradient associated with residential sprawl in greenfields. Indeed, a higher distance from the city center characterizes patches facing a sprawled expansion of residential settlements in rural areas, whereas "industrialization on greenfields" occurred mostly closer to Rome. P/A ratio was negatively correlated with Component 2: lower $\mathrm{P} / \mathrm{A}$ ratios characterize patches where conversion into rural land occurred. Component 3 groups larger patches characterized by industrial development on greenfields. Component 4 shows a gradient of residential land-use that differentiate between brownfield and greenfield residential densification. 
Table 2. GW-PCA significant loadings (>|0.35|) for each land-use trajectory and time interval.

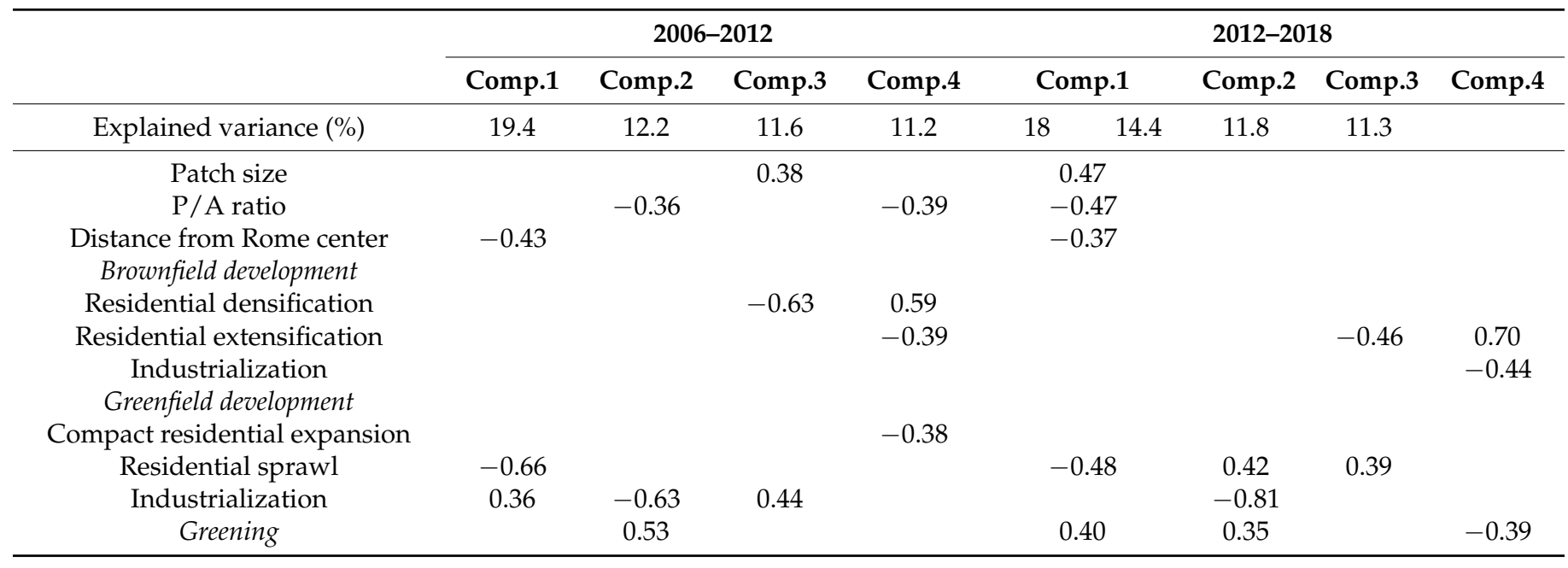

During the recession period, patch size (positive loadings) was opposed to P/A ratio and distance from Rome (negative loadings) along Component 1 , thus separating patches sprawling on rural areas (negative loadings) from those where a greening process occurred. Component 2 groups patches characterized by sprawl on greenfields. Component 3 shows a gradient of residential extensification, which separately groups extensification on brownfields (negative loadings) and sprawl into greenfields (positive loadings). Conversely, Component 4 is positively associated with the establishment of low-dense settlements on brownfields.

The GW-PCA allowed us also to individuate the most influential variables on the selected components at each location of land-use change (Figures 5 and 6). During the first period, all the patches that experienced a land-use change were associated to sprawl for Component 1 . Component 2 was associated to changes causing land consumption (i.e., industrial development on greenfields) in almost all the study area. On the other hand, during the second period, the results were less homogeneous from a spatial perspective. Indeed, greening emerged as a relevant variable not only far from the city center (Component 1), but also near Rome's downtown (Component 2).
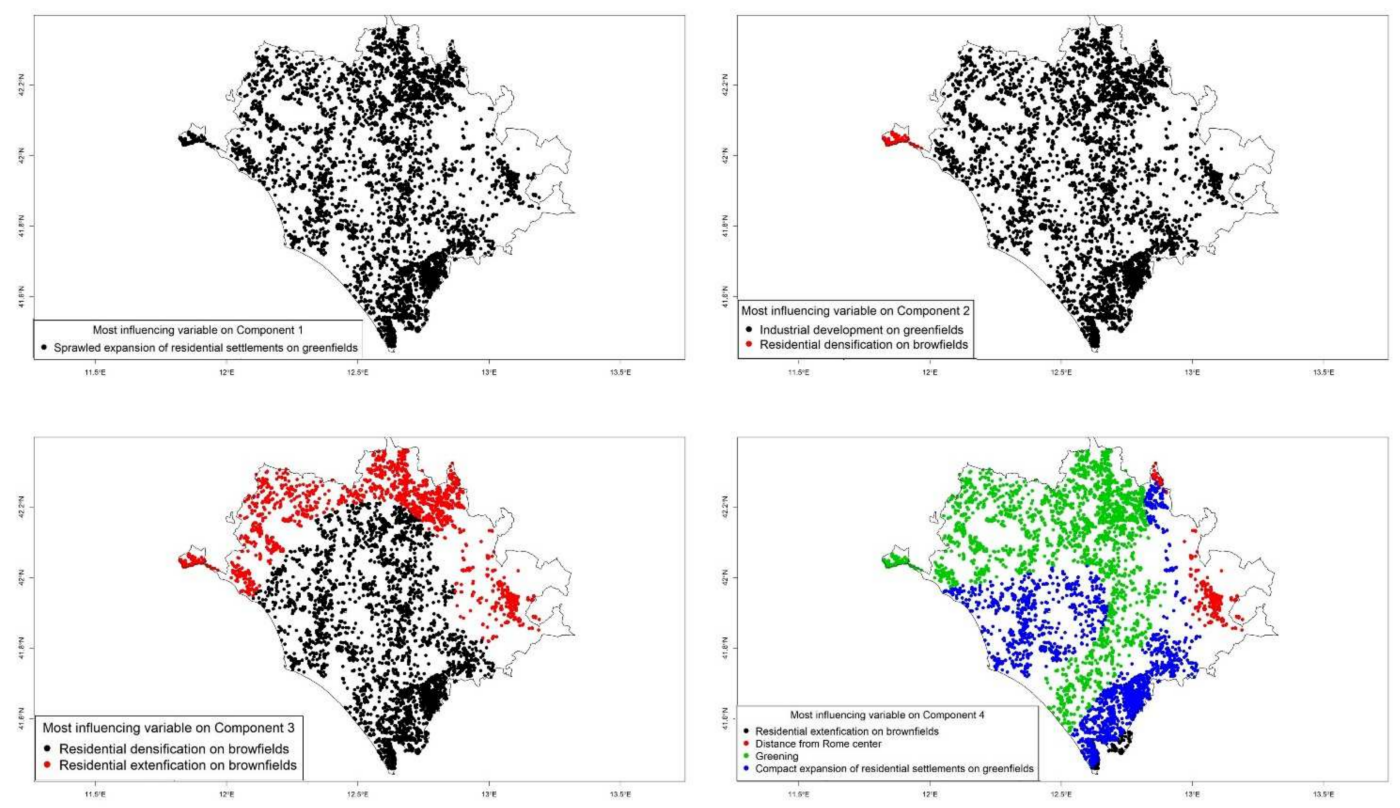

Figure 5. Most influential variables on components extracted by GW-PCA at each land-use change patch for the time interval 2006-2012. 

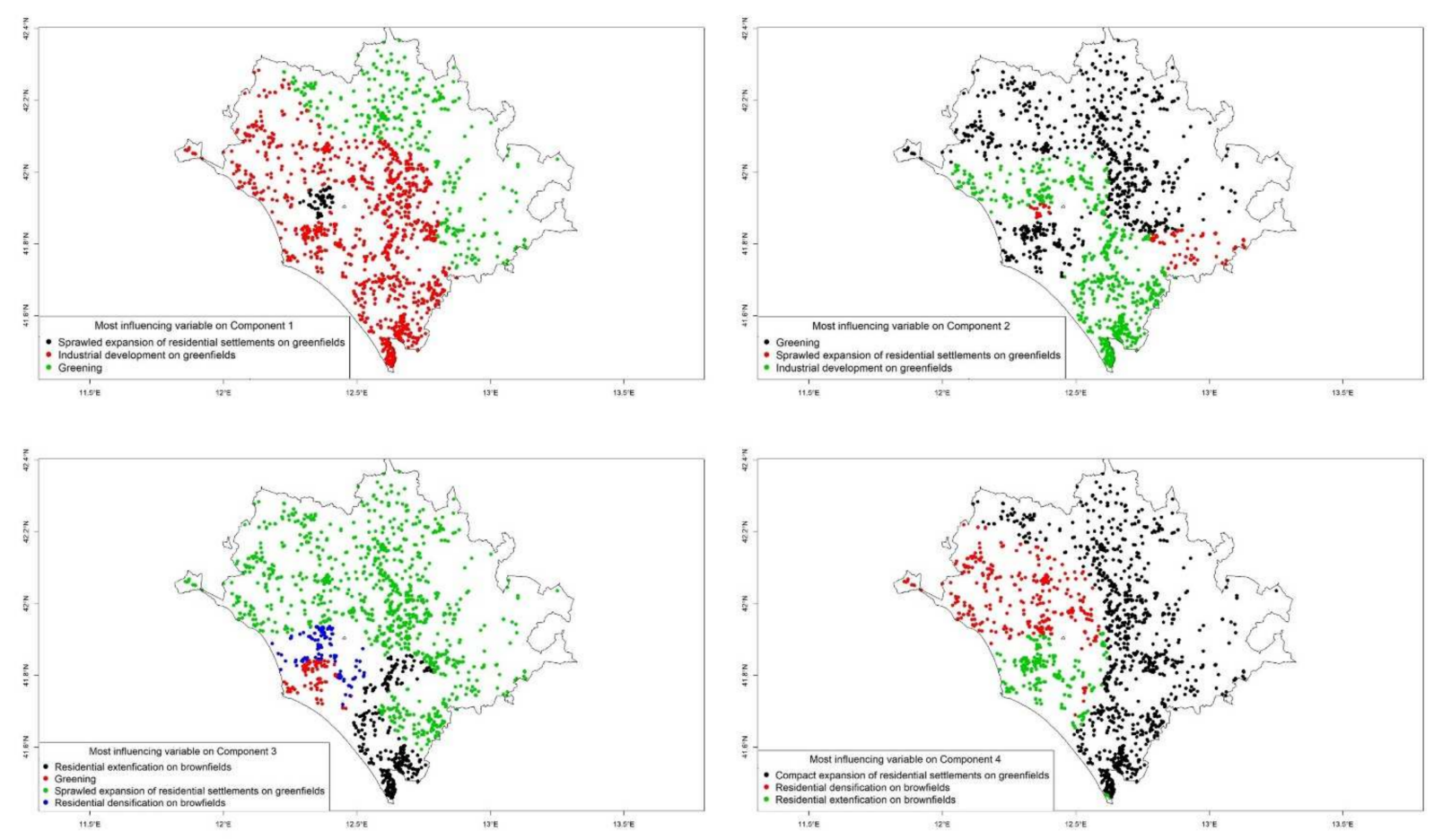

Figure 6. Most influential variables on components extracted by GW-PCA at each land-use change patch for the time interval 2012-2018.

\section{Discussion}

The present study, based on simplified landscape metrics and the application of the GW-PCA, has compared land-use dynamics in two subsequent periods between 2006 and 2018 in the Rome metropolitan region, with the main objective of assessing if specific land-use trajectories can be associated with the economic crisis. In this regard, the case study of a typical Mediterranean city, such as Rome, provides a unique opportunity to analyze the sensitivity in the short term of metropolitan areas to periods of economic expansion and recession. The underlying hypothesis that economic crises might contribute to a "land-saving urbanization" [34] has been confirmed by our results. Indeed, the landuse change analysis has clearly demonstrated that patterns of urban growth are different when comparing expansion and recession periods. Configuration (mean size), shape (P/A ratio), and position (distance from Rome center) of landscape patches experiencing landuse change differed from the first to the second period. Furthermore, the total number of patches under change was three times higher in 2006-2012 compared to the more recent period. These results are also in line with those of other recent studies in Europe, which have found a reduction of demographic dynamics and building activity during recession, resulting in slower land-use changes $[18,19]$.

The analysis of land-use trajectories revealed that urbanization on greenfields, despite a decrease from $40 \%$ of all changes in 2006-2012 to 30\% in 2012-2018, is still the main land-use change pattern in the study area, showing dynamics similar to other European metropolitan areas [21]. New built-up areas expanded primarily into agricultural areas ( $90 \%$ of changes during expansion, and more than $95 \%$ during recession). This evidence supports previous research identifying peri-urban cropland as the main land converted into new urban settlements [35-37]. Forests were rarely converted into urban land-uses, confirming, even in this case, the empirical results from earlier studies [38]. In the latter case, the low rate of change is probably due to the high level of protection of woodlands from land-use conversion by Italian normative and laws. The forest patches experiencing these changes are probably relict sites with low economic value in fringe areas linked to intensive use of private lands [39]. 
Despite the fact that natural land-uses were mainly converted into low-density residential settlements, a relevant rate of change of greenfields into industrial sites was also observed, especially during recession, when it became the main trajectory of change ( $23 \%$ of total landscape changes). Even if documented by previous studies for other Mediterranean cities $[19,40]$, this phenomenon is still a somewhat surprising result. However, this can be explained by a latent trend of industrial development during the late 2000s in Rome and other Mediterranean cities that has been consolidated in the last decade, caused by advances in production efficiency [41], being therefore marginally affected by recession. Greening, here intended as the conversion of urban marginal areas into croplands and forests, is the only trajectory experiencing an increase from 2006-2012 to 2012-2018, both in absolute (229 to 262 landscape patches) and in relative terms (6\% to nearly $20 \%$ ). As shown by previous studies in several countries in the Mediterranean basin [42-44], this phenomenon is mainly due to the progressive abandonment of marginal areas with a lower income, and a location at a greater distance from the city center $[45,46]$. The increase in forest cover has multiple benefits since it can provide several ecosystem services, including connectivity among natural ecosystems in terms of green infrastructure [42,47]. However, most of the newly established forests or shrubland are fire-prone forest types [48]. Therefore, an unplanned expansion of these areas may cause an enhanced fire risk, especially in the wildland-urban interface [49-51]. In this regard, active management promoting interventions to reduce fuel and improve the functionality and quality of new forests is required $[43,52]$.

The multivariate analysis results indicate significant changes in landscape configuration. Mean patch size and P/A ratio during expansion were significantly associated with compact expansion (both on brownfields and greenfields) and industrialization on greenfields. On the other hand, these indicators are associated only with residential sprawl into greenfields and greening during recession. Distance from the city center was associated with residential sprawl into greenfields, in both the first and second periods, when it also became significant to describe the emerging greening process. Indeed, all land-use change trajectories are progressively moving closer to the city center, demonstrating how the economic crisis is affecting the development of new brownfields or greenfields in the surrounding areas of the city center, increasing polarization between urban and rural areas.

The empirical results of our study suggest how periods of economic crisis may indirectly favor more sustainable urbanization. In this regard, it is worth noting that, assuming that urban containment is only a transitory effect of the crisis, future urban development can bring a new phase of residential sprawl [53]. Thus, despite the shift towards industrial development seeming to foster economic resilience in the metropolitan region in a time of crisis, this may not necessarily coincide with a sustainable and land-saving development model. Indeed, as shown by recent studies in Greece, industrial expansion, especially in rural areas, might be considered as a new form of urban sprawl $[19,54]$. Furthermore, even if the highlighted slight reduction of land-taking processes and of the urbanization scope in the urban region (e.g., an increase of settlement extensification on brownfields), comparing the two studied periods, settlement dynamics clearly show to be still affected by a trend toward further polarization focused on the urban core embodied by Rome, either in terms of economic activities or residential housing distribution. In the field of spatial planning strategies, this predicament-according to the wider EU proposed strategies [55] — calls to set up tools aimed to support polycentric settlement patterns $[56,57]$ referring also to the city-region development paradigm [58]. Indeed, this kind of spatial paradigm seems suitable to offset (in normative terms [59]) interurban inequalities, either by supporting sustainable "city-region" model-based endogenous economies and coping with, and overcoming the limits of, the inherited Italian traditional municipal-based planning model. In this direction, the (bio)city-region spatial model as proposed by Snyder [60] or, more generally, the "Urban bioregion" as a cross-scale planning model proposed in the field of bioregional planning studies [61-64], can add a further contribution to address fairness and ecosystem integrity issues. 
In this framework, the recently adopted strategic planning strategy on behalf of Rome Metropolitan City - although at its initial stage [65] — turns out to best fit with this prospect. Indeed, the mentioned strategic approach strongly draws on the vision based on an "inversion" strategy" aimed to reframe the Rome metro area city-countryside relationships according to the form of the "City Region" [66], mainly by protecting and enhancing (in socio-economic terms) the agroforestry matrix, along with the regional settlement middle-sized towns system as the counter-mold to reframe a balanced and sustainable region development and spatial framework. According to these goals, specific actions to contain urban sprawl on greenfields could include: (i) enhancing the protection level of marginal rural areas, including woodlots; (ii) increasing the quality of products and food safety, generating positive effects on the profitability of fringe agricultural productions; and (iii) encouraging brownfield development with appropriate incentives. Greenfield development should be limited only to high-density residential developments in agricultural contexts of low ecological value [67].

\section{Conclusions}

According to our study, economic downturns might have beneficial impacts on urban containment (i.e., reduction of the establishment of new settlements, and an increase of natural areas). However, these effects are not expected to modify the land-use structure, due to their transitory effect. Urban and regional planning should therefore capitalize on the "spontaneous" positive effects of recession, systematizing actions for urban containment by: (i) introducing a high level of protection of rural areas at the fringe; (ii) supporting the economic profitability of fringe cropland and peri-urban farms; (iii) managing new forests as a part of an organic green infrastructure; and (iv) encouraging development on brownfields and settlement/land rehabilitation.

Based on the concept of "crisis as an opportunity" [68], planning in Mediterranean Europe should consider post-crisis urbanity as an opportunity for sustainability. Urban planning should therefore seek to adapt urban forms to economic downturns, maximizing the beneficial transitory effects in each phase of expansion and recession. In this perspective, further advances of this study should include the application of the method (which combines traditional landscape metrics analysis with spatial multivariate procedures) to other contexts outside Mediterranean Europe. Furthermore, the effects of economic downturns should be examined not only in the short term, but also in the medium term, to understand how long the temporary effect on the reduction of land-taking processes may last in a specific area.

Author Contributions: Conceptualization, A.T. and L.S.; methodology, A.T., C.F. and L.S.; validation, A.T. and C.F.; formal analysis, A.T. and C.F.; data curation, W.M., G.Q. and R.S.; writing-original draft preparation, A.T., W.M., R.S. and L.S.; writing-review and editing, A.T., W.M., C.F., D.F. and G.Q.; supervision, D.F. and L.S.; project administration, A.T.; funding acquisition, D.F. All authors have read and agreed to the published version of the manuscript.

Funding: This research received no external funding.

Institutional Review Board Statement: Not applicable.

Informed Consent Statement: Not applicable.

Data Availability Statement: Publicly available datasets were analyzed in this study. This data can be found here: https:/ / land.copernicus.eu/local/urban-atlas (accessed on 30 September 2021).

Conflicts of Interest: The authors declare no conflict of interest.

\section{References}

1. Angel, S.; Parent, J.; Civco, D.L.; Blei, A.; Potere, D. The dimensions of global urban expansion: Estimates and projections for all countries, 2000-2050. Prog. Plan. 2011, 75, 53-107. [CrossRef]

2. Kroll, F.; Kabisch, N. The Relation of Diverging Urban Growth Processes and Demographic Change along an Urban-Rural Gradient. Popul. Space Place 2012, 18, 260-276. [CrossRef] 
3. Hertel, T.W.; West, T.A.P.; Boerner, J.; Villoria, N.B. A review of global-local-global linkages in economic land-use/cover change models. Environ. Res. Lett. 2019, 14, 053003. [CrossRef]

4. Nickayin, S.; Tomao, A.; Quaranta, G.; Salvati, L.; Morera, A.G. Going toward Resilience? Town Planning, Peri-Urban Landscapes, and the Expansion of Athens, Greece. Sustainability 2020, 12, 10471. [CrossRef]

5. Salvati, L.; Ciommi, M.T.; Serra, P.; Chelli, F.M. Exploring the spatial structure of housing prices under economic expansion and stagnation: The role of socio-demographic factors in metropolitan Rome, Italy. Land Use Policy 2018, 81, 143-152. [CrossRef]

6. Kane, K.; York, A.M.; Tuccillo, J.; Gentile, L.E.; Ouyang, Y. Residential development during the Great Recession: A shifting focus in Phoenix, Arizona. Urban Geogr. 2014, 35, 486-507. [CrossRef]

7. Aalbers, M. Geographies of the financial crisis. Area 2009, 41, 34-42. [CrossRef]

8. Pili, S.; Grigoriadis, E.; Carlucci, M.; Clemente, M.; Salvati, L. Towards sustainable growth? A multi-criteria assessment of (changing) urban forms. Ecol. Indic. 2017, 76, 71-80. [CrossRef]

9. Milan, B.F.; Creutzig, F. Municipal policies accelerated urban sprawl and public debts in Spain. Land Use Policy 2016, 54, 103-115. [CrossRef]

10. Wang, J.; Lin, Y.; Glendinning, A.; Xu, Y. Land-use changes and land policies evolution in China's urbanization processes. Land Use Policy 2018, 75, 375-387. [CrossRef]

11. Cho, S.-H.; Kim, S.G.; Roberts, R.K. Values of environmental landscape amenities during the 2000-2006 real estate boom and subsequent 2008 recession. J. Environ. Plan. Manag. 2011, 54, 71-91. [CrossRef]

12. Duvernoy, I.; Zambon, I.; Sateriano, A.; Salvati, L. Pictures from the other side of the fringe: Urban growth and peri-urban agriculture in a post-industrial city (Toulouse, France). J. Rural. Stud. 2018, 57, 25-35. [CrossRef]

13. Di Feliciantonio, C.; Salvati, L. 'Southern' Alternatives of Urban Diffusion: Investigating Settlement Characteristics and SocioEconomic Patterns in Three Mediterranean Regions. Tijdschr. voor Econ. en Soc. Geogr. 2014, 106, 453-470. [CrossRef]

14. Castles, F.G.; Ferrera, M. Home Ownership and the Welfare State: Is Southern Europe Different? South Eur. Soc. Politi. 1996, 1, 163-185. [CrossRef]

15. Zambon, I.; Benedetti, A.; Ferrara, C.; Salvati, L. Soil Matters? A Multivariate Analysis of Socioeconomic Constraints to Urban Expansion in Mediterranean Europe. Ecol. Econ. 2018, 146, 173-183. [CrossRef]

16. Bajocco, S.; Ceccarelli, T.; Smiraglia, D.; Salvati, L.; Ricotta, C. Modeling the ecological niche of long-term land use changes: The role of biophysical factors. Ecol. Indic. 2016, 60, 231-236. [CrossRef]

17. Schneider, F.; Kallis, G.; Martinez-Alier, J. Crisis or opportunity? Economic degrowth for social equity and ecological sustainability. Introduction to this special issue. J. Clean. Prod. 2010, 18, 511-518. [CrossRef]

18. Salvati, L.; Sateriano, A.; Grigoriadis, E. Crisis and the city: Profiling urban growth under economic expansion and stagnation. Lett. Spat. Resour. Sci. 2015, 9, 329-342. [CrossRef]

19. Tomao, A.; Quaranta, G.; Salvia, R.; Vinci, S.; Salvati, L. Revisiting the 'southern mood'? Post-crisis Mediterranean urbanities between economic downturns and land-use change. Land Use Policy 2021, 105740. [CrossRef]

20. Lambin, E.F.; Meyfroidt, P. Land use transitions: Socio-ecological feedback versus socio-economic change. Land Use Policy 2010, 27, 108-118. [CrossRef]

21. Salvati, L.; Quatrini, V.; Barbati, A.; Tomao, A.; Mavrakis, A.; Serra, P.; Sabbi, A.; Merlini, P.; Corona, P. Soil occupation efficiency and landscape conservation in four Mediterranean urban regions. Urban For. Urban Green. 2016, 20, 419-427. [CrossRef]

22. Zhou, X.; Chen, H. Impact of urbanization-related land use land cover changes and urban morphology changes on the urban heat island phenomenon. Sci. Total. Environ. 2018, 635, 1467-1476. [CrossRef] [PubMed]

23. Li, F.; Zhou, T. Effects of urban form on air quality in China: An analysis based on the spatial autoregressive model. Cities 2019, 89, 130-140. [CrossRef]

24. Zhou, H.; Gao, H. The impact of urban morphology on urban transportation mode: A case study of Tokyo. Case Stud. Transp. Policy 2018, 8, 197-205. [CrossRef]

25. Chen, H.C.; Han, Q.; de Vries, B. Urban morphology indicator analyzes for urban energy modeling. Sustain. Cities Soc. 2020, 52, 101863. [CrossRef]

26. Lloyd, C.D. Analysing population characteristics using geographically weighted principal components analysis: A case study of Northern Ireland in 2001. Comput. Environ. Urban Syst. 2010, 34, 389-399. [CrossRef]

27. Gollini, I.; Lu, B.; Charlton, M.; Brunsdon, C.; Harris, P. Gwmodel: An R package for exploring spatial heterogeneity using geographically weighted models. J. Stat. Softw. 2015, 63, 1-50. [CrossRef]

28. Lu, B.; Harris, P.; Charlton, M.; Brunsdon, C. The GWmodel R package: Further topics for exploring spatial heterogeneity using geographically weighted models. Geo-Spat. Inf. Sci. 2014, 17, 85-101. [CrossRef]

29. Egidi, G.; Halbac-Cotoara-Zamfir, R.; Cividino, S.; Quaranta, G.; Salvati, L.; Colantoni, A. Rural in town: Traditional agriculture, population trends, and long-term urban expansion in metropolitan Rome. Land 2020, 9, 53. [CrossRef]

30. Salvati, L.; Morelli, V.G.; Rontos, K.; Sabbi, A. Latent exurban development: City expansion along the rural-to-urban gradient in growing and declining regions of southern Europe. Urban Geogr. 2013, 34, 376-394. [CrossRef]

31. Salvati, L.; Carlucci, M. Urban Growth and Land-Use Structure in Two Mediterranean Regions. SAGE Open 2014, 4, 215824401456119. [CrossRef]

32. Demšar, U.; Harris, P.; Brunsdon, C.; Fotheringham, A.S.; McLoone, S. Principal Component Analysis on Spatial Data: An Overview. Ann. Assoc. Am. Geogr. 2013, 103, 106-128. [CrossRef] 
33. Harris, P.; Brunsdon, C.; Charlton, M. International Journal of Geographical Information Science Geographically weighted principal components analysis Geographically weighted principal components analysis. Int. J. Geogr. Inf. Sci. 2011, 25, $1717-1736$. [CrossRef]

34. Salvati, L.; Ricciardo Lamonica, G. Containing urban expansion: Densification vs greenfield development, socio-demographic transformations and the economic crisis in a Southern European City, 2006-2015. Ecol. Indic. 2020, 110, 5923. [CrossRef]

35. Paliogiannis, C.; Koedam, N.; Cliquet, A. The impact of the economic crisis on the implementation of the EU Nature Directives in Greece: An expert-based view. J. Nat. Conserv. 2019, 48, 36-46. [CrossRef]

36. Gasparella, L.; Tomao, A.; Agrimi, M.; Corona, P.; Portoghesi, L.; Barbati, A. Italian stone pine forests under Rome's siege: Learning from the past to protect their future. Landsc. Res. 2017, 42, 211-222. [CrossRef]

37. Salvati, L.; Gasparella, L.; Munafò, M.; Romano, R.; Barbati, A. Figuring the features of the Roman Campagna: Recent landscape structural. Ann. Silvic. Res. 2017, 41, 20-28. [CrossRef]

38. Hayek, U.W.; Jaeger, J.A.G.; Schwick, C.; Jarne, A.; Schuler, M. Measuring and Assessing Urban Sprawl: What are the Remaining Options for Future Settlement Development in Switzerland for 2030? Appl. Spat. Anal. Policy 2011, 4, 249-279. [CrossRef]

39. Falco, E.; Chiodelli, F. The transfer of development rights in the midst of the economic crisis: Potential, innovation and limits in Italy. Land Use policy 2018, 72, 381-388. [CrossRef]

40. Chorianopoulos, I.; Pagonis, T.; Koukoulas, S.; Drymoniti, S. Planning, competitiveness and sprawl in the Mediterranean city: The case of Athens. Cities 2010, 9, 126. [CrossRef]

41. Arena, S.; Roda, I.; Chiacchio, F. Integrating modelling of maintenance policies within a stochastic hybrid automaton framework of dynamic reliability. Appl. Sci. 2021, 11, 2300. [CrossRef]

42. Barbati, A.; Corona, P.; Salvati, L.; Gasparella, L. Natural forest expansion into suburban countryside: Gained ground for a green infrastructure? Urban. For. Urban. Green. 2013, 12, 36-43. [CrossRef]

43. Tomao, A.; Quatrini, V.; Corona, P.; Ferrara, A.; Lafortezza, R.; Salvati, L. Resilient landscapes in Mediterranean urban areas: Understanding factors influencing forest trends. Environ. Res. 2017, 156. [CrossRef] [PubMed]

44. Palmero-Iniesta, M.; Pino, J.; Pesquer, L.; Espelta, J.M. Recent forest area increase in Europe: Expanding and regenerating forests differ in their regional patterns, drivers and productivity trends. Eur. J. For. Res. 2021, 140, 793-805. [CrossRef]

45. Cimini, D.; Tomao, A.; Mattioli, W.; Barbati, A.; Corona, P. Assessing impact of forest Cover Change dynamics on High Nature Value farmland in Mediterranean mountain landscape. Ann. Silvic. Res. 2013, 37, 29-57. [CrossRef]

46. Salvati, L. Exurban Development and Landscape Diversification in a Mediterranean Suburban Area. Scottish Geogr. J. 2014, 130, 22-34. [CrossRef]

47. Ferrari, B.; Quatrini, V.; Barbati, A.; Corona, P.; Masini, E.; Russo, D. Conservation and enhancement of the green infrastructure as a nature-based solution for Rome's sustainable development. Urban. Ecosyst. 2019, 22, 865-878. [CrossRef]

48. Moreira, F.; Viedma, O.; Arianoutsou, M.; Curt, T.; Koutsias, N.; Rigolot, E.; Barbati, A.; Corona, P.; Vaz, P.; Xanthopoulos, G.; et al. Landscape-wildfire interactions in southern Europe: Implications for landscape management. J. Environ. Manage. 2011, 92, 2389-2402. [CrossRef]

49. Galiana-Martín, L. Spatial Planning Experiences for Vulnerability Reduction in the Wildland-Urban Interface in Mediterranean European Countries. Eur. Countrys. 2017, 9, 577-593. [CrossRef]

50. Mancini, L.D.; Elia, M.; Barbati, A.; Salvati, L.; Corona, P.; Lafortezza, R.; Sanesi, G. Are Wildfires Knocking on the Built-Up Areas Door? Forests 2018, 9, 234. [CrossRef]

51. D’Este, M.; Ganga, A.; Elia, M.; Lovreglio, R.; Giannico, V.; Spano, G.; Colangelo, G.; Lafortezza, R.; Sanesi, G. Modeling fire ignition probability and frequency using Hurdle models: A cross-regional study in Southern Europe. Ecol. Process. $2020,9,54$. [CrossRef]

52. Colantoni, A.; Egidi, G.; Quaranta, G.; D'Alessandro, R.; Vinci, S.; Turco, R.; Salvati, L. Sustainable Land Management, Wildfire Risk and the Role of Grazing in Mediterranean Urban-Rural Interfaces: A Regional Approach from Greece. Land 2020, 9, 21. [CrossRef]

53. Zambon, I.; Serra, P.; Sauri, D.; Carlucci, M.; Salvati, L. Beyond the 'Mediterranean city': Socioeconomic disparities and urban sprawl in three Southern European cities. Geogr. Ann. Ser. B Hum. Geogr. 2017, 99, 319-337. [CrossRef]

54. Chorianopoulos, I.; Tsilimigkas, G.; Koukoulas, S.; Balatsos, T. The shift to competitiveness and a new phase of sprawl in the Mediterranean city: Enterprises guiding growth in Messoghia-Athens. Cities 2014, 39, 133-143. [CrossRef]

55. ESPON. European Spatial Development Perspective. In Towards Balanced and Sustainable Development of the Territory of the EU; First Official draft (Noordwijk); CEC: Luxembourg, Luxemburg, 1997.

56. Ravetz, J. City-Region 2020: Integrated Planning for a Sustainable Environment; Routledge: London, UK, 2016 ; ISBN 9781134900923.

57. Hall, P.; Pain, K. The Polycentric Metropolis: Learning from Mega-City Regions in Europe; Routledge: London, UK, 2006; ISBN 9781849773911.

58. Rodríguez-Pose, A. The Rise of the "City-region" Concept and its Development Policy Implications. Eur. Plan. Stud. 2008, 16, 1025-1046. [CrossRef]

59. Davoudi, S. EUROPEAN BRIEFING: Polycentricity in European spatial planning: From an analytical tool to a normative agenda. Eur. Plan. Stud. 2003, 11, 979-999. [CrossRef]

60. Snyder, G. Coming to the watershed. In Futures by Design. The Practice of Ecological Planning; Aberley, D., Ed.; New Society Publisher: Gabriola Island, BC, Canada, 1994; pp. 14-26. 
61. Dasmann, R. Some thought on ecological planning. In Futures by Design. Pract. Ecol. Plan; Aberley, D., Ed.; New Society Publisher: Gabriola Island, BC, Canada, 1994; pp. 36-43.

62. Thayer, R.L. Life Place: Bioregional Thought and Practice; University of California Press: Berkeley, CA, USA, 2003 ; ISBN 0520213122.

63. Church, S.P. Exploring urban bioregionalism: A synthesis of literature on urban nature and sustainable patterns of urban living. Sapiens 2015, 7(1), 1-11.

64. Magnaghi, A. The Territorialist Approach to Urban Bioregions. In Bioregional Planning and Design: Volume I; Fanfani, D., Matarán Ruiz, A., Eds.; Springer International Publishing: New York, NY, USA, 2020; pp. 33-61.

65. Città Metropolitana Roma Piano Strategico Metropolitano Documento Preliminare. Available online: https://static. cittametropolitanaroma.it/uploads/Relazione_allegato_decreto_def.pdf (accessed on 20 August 2021).

66. Tocci, W. Roma Come Se. Alla Ricerca del Futuro per la Capitale; Donzelli: Roma, Italy, 2020; p. VI-276.

67. Bičík, I.; Jeleček, L.; Štěpánek, V. Land-use changes and their social driving forces in Czechia in the 19th and 20th centuries. Land Use Policy 2001, 18, 65-73. [CrossRef]

68. Florida, R. The Great Reset: How the Post-Crash Economy Will Change the Way We Live and Work; Harper Collins: London, UK, 2011. 